\title{
TINJAUAN TINGKAT KESEGARAN JASMANI PADA SISWA PUTERA YANG MENGIKUTI EKSTRAKURIKULER GULAT DI SMP NEGERI 30 PADANG
}

\author{
Hasriwandi Nur ${ }^{1}$, Madri $\mathrm{M}^{2}$, Zalfendi ${ }^{3}$ \\ ${ }^{1}$ Program Studi Pendidikan Jasmani Kesehatan dan Rekreasi, Fakultas Ilmu Keolahragaan, \\ Universitas Negeri Padang, Jalan Prof. DR. Hamka Air Tawar Barat, Padang, 25132, \\ Indonesia \\ ${ }^{2}$ Program Studi Pendidikan Jasmani Kesehatan dan Rekreasi, Fakultas Ilmu Keolahragaan, \\ Universitas Negeri Padang, Jalan Prof. DR. Hamka Air Tawar Barat, Padang, 25132, \\ Indonesia
}

E-mail: Edwarsyah@fik.unp.ac.id , Zalfendi@ fik.unp.ac.id

\begin{abstract}
Abstrak
Masalah dalam penelitian ini berawal dari rendahnya tingkat kesegaran jasmani siswa, karena kurangnya minat siswa mengikuti ekstrakurikuler gulat. Tujuan penelitian ini untuk mengetahui tingkat kesegaran jasmani siswa Putera yang mengikuti ekstrakurikuler gulat di SMP Negeri 30 Padang.

Jenis penelitian ini adalah deskriptif yaitu penelitian yang menggambarkan variabel bebas dan variabel terikat yang memuat argumen - argumen variabel yang diteliti. Populasi dalam penelitian ini adalah seluruh siswa yang mengikuti ekstrakurikuler gulat di SMP Negari 30 Padang yang berjumlah 40 orang. Dalam penelitian ini sampel diambil secara total sampling yaitu seluruh siswa putra yang mengambil ekstrakurikuler gulat berjumlah 40 orang. Tes yang digunakan untuk kesegaran jasmani adalah tes kesegaran jasmani adalah tes Kesegaran Jasmani Indonesia (TKJI) putra usia 13-16 tahun.
\end{abstract}

\section{Kata Kunci :Kesegaran Jasmani}

\section{PENDAHULUAN}

Pendidikan jasmani dan olah raga merupakan sebuah investasi jangka panjang dalam upaya pembinaan mutu sumberdaya manusia Indonesia. Hasil yang diharapkan itu akan dicapai setelah masa yang cukup lama. Karena itu upaya pembinaan warga masyarakat dan peserta didik melalui pendidikan jasmani dan olahraga membutuhkan kesabaran dan keikhlasan untuk berkorban.

Sebagai upaya pembinaan mutu sumber daya manusia, pendidikan jasmanai dan olahraga dilembaga pendidikan formal dapat berkembang lebih pesat agar mampu menjadi landasan bagi pembinaan keolahragaan nasional. Proses pembentukan sikap dan pembangkitan motivasi harus dimulai sejak seseorang berada di bangku TK, sekolah dasar sampai dengan perguruan tinggi.

Olahraga adalah salah satu bentuk dari upaya peningkatan kualitas manusia Indonesia yang diarahkan pada pembentukan watak dan kepribadian, disiplin dan sportifitas yang tinggi, serta peningkatan prestasi yang dapat membangkitkan rasa kebanggaan nasional. Itulah sebabnya semua tingkat sekolah dari TK, Sekolah Dasar, sampai ke Perguruan Tinggi, olahraga selalu dimasukkan dalam salah satu mata pelajaran yang harus di ajarkan, baik dalam program intrakurikuler maupun dalam program ekstrakurikuler. Sebagai mata pelajaran dalam intraakurikuler olahraga ditekankan pada pembinaan pendidikan jasmani dan kesehatan sehingga dinamakan pendidikan jasmani dan kesehatan dengan waktu 2 jam pelajaran seminggu.

Sebagai salah satu kegiatan ekstrakurikuler olahraga dimaksudkan untuk menggali bakat-bakat olahraga yang ada pada masing-masing siswa, bakat tersebut dibina lewat latihan-latihan olahraga pilihannya dengan harapan dari sekolah-sekolah ini muncul olahragawan yang berpotensi.

Ada bermacam-macam kegiatan ekstrakurikuler yang biasanya diselenggarakan oleh sekolah, antara lain gulat. Olahraga ini akan segera populer karena, olah raga ini sudah mulai memasyarakat. 
Dalam UUD No.3 Tabun 2005 Tentang Sistem Keolahragaan Nasional (2005:6) Mengatakan bahwa:

"Keolahragaan Nasional bertujuan memelihara dan meningkatkan kebugaran jasmani, prestasi, kualitas hidup manusia, menanamkan nilai moral dan akhlak mulia, sportifitas, disiplin dan membina persatuan bangsa, memperkukuh pertahanan nasional, serta mengangkat harkat, martabat dan kehormatan bangsa"

Berdasarkan hal itu guru pendidikan jasmani dan para pelatih olahraga diharapkan memiliki pengetahuan, keterampilan dan pengalaman yang memadai agar dapat mencapai suatu keberhasilan dalam mengajar dan melatih oleh seorang guru atau pelatih sangat penting dalam meningkatkan prestasi olahraga yang diharapkan. Keberhasilan guru dalam megajar akan membawa dampak positif terhadap kuaitas hidup.

Menutur hasil seminar nasional dinyatakan bahwa, seseorang yang memiliki kesegaran jasmani dapat diartikan sebagai orang yang mempunyai kesanggupan dan kemampuan untuk melakukan pekerjaannya dengan efisien tanpa menimbulkan kelelahan yang berarti. Kesegaran jasmani ada yang berhubungan erat dengan keterampilan atau skill.

Dari penjelasan di atas kegiatan ekstrakurikuler penjas adalah salah satu kegiatan untuk mengembangkan keterampilan siswa dan hendaknya sekolah dapat mengelola dan melaksanakan kegiatan ekstrakurikuler secara terkoordinir, dengan ada kata kegiatan ekstrakurikuler penjas harus diperhatikan khusus dari para pengelola lembaga pendidikan dalam rangka mengembangkan keterampilan siswa karena siswa merupakan aset bangsa yang sangat berharga.

SMP Negeri 30 yang beralamat di JI.Baru Andalas Padang mempunyai prestasi akademik maupun non akademik yang membuat SMP Negeri 30 Padang dikategorikan sekolah unggulan. Banyaknya kelas di SMP Negeri 30 Padang : kelas $\mathrm{X}$ ada 7 kelas, tiap-tiap kelas rata-rata berjumlah 40 siswa, kelas XI dan XII ada tiga jurusan yaitu : IPA, IPS, dan Bahasa.

Dalam kegiatan ekstrakurikuler harus ditunjang oleh guru beberapa hal. Salah satunya fasilitas sekolah termasuk lapangan olahraga untuk memperlancar kegiatan ekstrkurikuler. Sebelum mencapai tujuan ekstrakurikuler olahraga, kita harus terlebih dahulu mempunyai kamauan yang tinggi dan diiringi dengan perbuatan dan tindakan salah satunya dengan cara senang atau rutinnya melakukan kegiatan dalam latihan.

Pelaksanaan dan pembinaan kegiatan ekstrakurikuler dapat dilakukan dengan bermacam-macam kegiatan seperti yang telah dijelaskan pada kegiatan ekstrakurikuler di atas. Kegiatan ekstrkurikuler pada cabang olahraga misalnya, bisa dilakukan dengan kegiatan ekstarkurikuler gulat dan lain-lainnya. Tegantung pada diri kita sendiri kegiatan olahraga yang ada. Maka penulis akan meneliti tentang Tingkat Kesegaran Jasmani Siswa Ektrakurikuler Gulat.

Brdasarkah pengamatan penulis di SMP Negari 30 Padang mengenai kegiatan ekstrakurikuler kurang terlaksana dengan baik, hal ini mungkin disebabkan oleh beberapa faktor seperti; minat siswa, dorongan kepala sekolah, dorongan guru, kualitas pelatih, mekanisme organisasi, kemampuan siswa, sarana prasarana program latihan, sumber dana yang tersedia, pengaruh orang tua, dan pengaruh lingkungan.

Selain itu juga berdasarkan pengamatan penulis dari salah seorang guru olahraga Penjas di SMP Negeri 30 Padang dapat digambarkan bahwa kegiatan ekstrkurikuler Penjas khususnya olahraga gulat jarang diikuti oleh siswa putra dan putri kelas I, II,III masih banyak siswa yang malas mengikutinya hal ini mungkin disebabkan oleh minat siswa yang rendah.

Belum lancamya pelaksanaannya kegiatan ekstrkurikuler gulat hal ini akan menimbulkan bermacam-macam dugaan antara lain; kurangnya dukungan kepala sekolah, guru penjas, minat siswa serta rendahnya dukungan orang tua.

Sejalan dengan pendekatan pada pendidikan jasmani dijelaskan bahwa model perkembangan di definisikan sebagai suatu pendekatan pendidikan jasmani, yang dimaksud adalah : mendidik anak dalam menggunakan tubuhnya, agar mereka dapat bergerak lebih efektif dan efisien dalam banyaknya macam gerakan dasar. Kemampuan dasar dapat diterapkan terhadap banyaknya macam gerakan keterampilan baik yang perkembang berhubungan dengan olahraga maupun tidak.

Pada pokok model perkembangan difokuskan pada pemberian pengalaman gerakan untuk dikembangkan, permainan, olahraga, menari dan lainnya yang membantu sebagai sarana untuk meningkatkan keterampilan. Dan jelaskan pula bahwa bahwa aktifitas seperti : menari, permainan, senam pada tingkat sekolah 
dasar memainkan peranan yang integral dalam perkembangan, penghalusan dan bermanfaat pada keterampilan dasar gerakan dasar (Gabbard, 1987), namun demikian perencanaan program latihan pada umumnya. Gabbard mengatakan bahwa program latihan dapat mencapai optimal bila dilakukan sesuai dengan prinsip dasar latihan dan penerapannya dilakukan dengan hati-hati.

Untuk mengetahui seberapa tinggi tingkat kesegaran jasmani seseorang harus ada pengukuran kesegaran jasmani. Salah satu alat untuk mengukur tingkat kesegaran jasmani adalah Test TKJI 2010" Tes ini bertujuan untuk mengetahui tingkat kesegaran jasmani seseorang". Pelaksanaannnya sebagai berikut:

1) Alat dan perlengkapan : a) Suatu permukaan datar yang tidak licin, b) Meteran, c) Alat/gantungan gantung siku tekuk, d) pluit, e) kapur, d) kertas dan alat tulis

2) Persiapan responder : a) Responder melakukan pemanasan dahulu, terutama otot lengan dan tungkai.

1. Karakteristik Cabang Olah Raga Gulat

Gulat (Wresling) seperti jenis olah raga lainnya, mentaati semua peraturan permainan (Rule of the game) dan menetapkan dalam praktek dengan tujuan mengunci dan memenangkan angka, peraturan ini diterapkan pada semua gaya yang di akui dalam pergulatan modern (gaya romawi yunani dan gaya bebas).

Gaya romawi yunani diarang memegang lawan pada bagian punggung atau mencegal, atau dengan menggunakan kaki secara aktif dalam melakukan serangan. Sedangkan pada gaya bebas diperkenankan memegang kaki lawan, atau mencegal dan menggunakan kaki dalam melakukan gerakan atau serangan.

Sejak masuknya jenis-jenis olah raga baru ke Indonesia seperti sumo, wushu, ataupun olah raga sejenis lainnya, gulat memang seakan ditinggalkan. Padahal sejarah hingga berkembangnya olahraga ini di Indonesia melalui beberapa tahap yang cukup sulit, diantaranya keberadaannya yang hampir benarbenar tersingkir sejak Jepang datang membawa olahraga macam Judo serta Kempo.

Hingga akhirnya gulat kembali dipopulerkan pada tahun 1959 dengan adanya pertandingan di Bandung. Olahraga fisik ini juga. dilombakan pada perhelatan akbar SEA GAMES IV pads tahun 1962 sehingga Indonesia secara singkat harus mendirikan asosiasi khusus gulat untuk melakukan perekrutan atlet dan memberikan pendidikan olahraga bagi calon atlet.

Asosiasi itu bernama Persatuan Gulat Amatir Seluruh Indonesia atau disingkat PGSI. Asosiasi ini didirikan pada 7 Februari 1960 dan mewadahi olahraga, cabang ini hingga sekarang. PGSI berada di bawah KONI dan secara teratur melakukan pelatihan atlet untuk mengikuti berbagai kejuaraan baik tingkat regional ataupun internasional.

Aktivitas terbaru gulat Indonesia adalah mengikuti perhelatan Asian Games XVI di Guangzhou. Namur atlet kita, gagal mengukir prestasi pada event yang diselenggarakan pada tahun 2010 kemarin. Kegagalan ini dinilai karena kurangnya pelatihan serta pengalaman bertanding para atlet, sehingga pada saat bertanding mereka kehilangan kepercayaan diri.

Untuk mengantisipasi kegagalan yang sama di perhelatan lainnya, pihak PGSI sudah melakukan berbagai langkah pencegahan, termasuk diantaranya dengan melakukan pelatihan olahraga yang lebih intensif, sering mengikuti kejuaraan untuk mendapatkan pengalaman bertanding serta merekrut atlet-atlet berbakat baru dari seluruh Indonesia.

Saat ini, atlet gulat yang berbakat banyak didapatkan dari wilayah Kalimantan Timur. Selain pembibitan atlet, daerah ini juga cukup banyak mendukung asosiasi dengan pelaksanakan pembinaan terhadap atlet gulat mulai dari tingkat dini hingga senior. Usaha ini dilakukan menjelang event Asia Games XXVI yang akan dilakukan di Jakarta.

Olah raga ini sudah lama berkembang di Sumatera Barat mulai dari tahun 1971 sampai sekarang masih menunjukkan aktifitas sangat baik sekali. Pada, tahun 2005 olahraga gulat termasuk salah satu cabang olag ragaandalan Sumatera Barat dari 43 cabang olahraga yang ada di Sumatera Barat. Hal ini dapat dilihat pada, pembinaan olahraga di KONI Sumatera Barat dimana gulat termasuk cabang olah raga super prioritas.

Prestasi yang dimiliki pegulat Sumatera Barat pada setiap kejuaraan yang diikuti selalu menyumbangkan medali seperti emas, perak, perunggu yang diperoleh melalui open turnamen, kejuaraan pelajar, kejumas dan Asian Game Tahun 1987 di Jakarta. Tiga atlet Sumatera mewakili Indonesia atas nama Rusdi, Afrizal Rush dan Afrizal Ramba. Ketiga atlet Sumatera Barat tersebut menyumbangkan medali emas untuk kontingen Indonesia.

Tinjauan Tingkat Kesegaran Jasmani Pada Siswa Putera ...69 Edwarsyah $^{1}$, Zalfendi $^{2}$ 


\section{METODE}

Jenis penelitian ini adalah deskriptif yang bertujuan untuk mengetahui tingkat kesegaran jasmani yang mengikuti ekstrakurikuler gulat pada siswa SMP Negeri 30 Padang Tahun 2014. Hal ini sesuai dengan pendapat Arikunto (1962:23) "penelitian deskriptif adalah penelitian yang bermaksud menguji hipotesis tertentu tapi hanya menggambarkan apa adanya suatu variabel, gejala atau keadaan.

Penelitian ini akan mengungkapkan atau menggambarkan tingkat kesegaran jasmani siswa yang mengikuti ekstrakurikuler gulat di SMP Negeri 30 Padang. Oleh karena itu metode yang digunakan adalah metode untuk penelitian lebih lanjut diperlukan hal-hal sebagai berikut: Tempat penelitian dilaksanakan di SMP Negeri 30 Padang. Waktu pelaksanaan penelitian ini dilakukan pada bulan Juli - Agustus Tahun 2014.

Populasi dalam penelitian ini adalah seluruh siswa yang mengikuti kegiatan ekstrakurikuler gulat di SMP Negeri 30 Padang Tahun 2014, yang semuanya bedumlah 40 siswa. Menurut Arikunto (1993:102) mengatakan bahwa "populasi adalah keseluruhan subyek penelitian". Populasi semuanya adalah siswa SMP Negeri 30 Padang yang mengikuti kegiatan ekstrakurikuler gulat.

Dengan demikian populasi yang digunakan dalam penelitian ini sudah memenuhi syarat sebagai populasi. Sampel dalam penelitian ini adalah siswa putra yang mengikuti ekstakurikuler SMP Negeri 30 Padang.

Tidak semua populasi harus dijadikan sampel, sebagai sampel bisa mengambil sebagian dari populasi asal sampel tersebut bisa mewakili populasi. Sebenamya tidak ada suatu ketetapan yang mutlak berapa persen dari jumlah populasi untuk dipilih sebagai sampel.

Menurut Suharsimi Arikunto (2000:112) adalah "apabila jumlah subyeknya kurang dari 100 maka sebaiknya populasi diambil semua bagian sampel, apabila jumlah subyeknya besar dapat diambil $10 \%-15 \%$, atau $20 \%-25 \%$ atau lebih".

Hal ini tergantung dari : 1) Kemampuan peneliti dilihat dari waktu, tenaga dan dana, 2) sempit luasnya wilayah pengamatan dari setiap subyek, karena hal ini menyangkut banyak sedikitnya data, dan 3) besar kecilnya resiko yang harus ditanggung oleh peneliti.

Dalam penelitian ini dengan pertimbangan-pertimbangan

1. Terbatasnya waktu, tenaga dan dana, karena peneliti terbatas masa penyelesaian peelitian, tenaga yang terbatas dan dana yang terbatas.

2. Resiko yang ditanggung sangat kecil dalam arti tidak membahayakan maka peneliti akan mengambil 40 dari 40 siswa sebagai sampel, penelitian ini, ialah 40 siswa untuk mengikuti ekstrkurikuler gulat.

Cara pemilihan sampel. menggunakan teknik total sampling, dimana dari semua populasi dijadikan sampel keseluruhannya yaitu sebanyak 40 orang siswa yang mengikuti ekstrkurikuler gulat. Hal ini sejalan dengan apa yang dikemukakan arikunto (1998:34) mengatakan bahwa "populasi yang kurang dari 100 oraing sebaiknya semua dijadikan sampel".

Tabel 2

Sampel Penelitian

\begin{tabular}{|c|c|c|}
\hline No & $\begin{array}{c}\text { Ekstrkuriku } \\
\text { ler }\end{array}$ & $\begin{array}{c}\text { Jumlah } \\
\text { Peserta }\end{array}$ \\
\hline 1 & Gulat & 40 Orang \\
\hline & Jumlah & 40 Orang \\
\hline
\end{tabular}

Data yang dikumpulkan dalam penelitian ini adalah data primer dan data sekunder. Data primer diperoleh dari tes kesegaran jasmani terhadap, siswa yang terpilih menjadi sampel. Sedangkan data sekunder diambil dari guru penjasorkes SMP Negeri 30 Padang.

Sumber data dalam penelitian ini adalah siswa SMP Negeri 30 Padang yang mengikuti ekstrakurikuler gulat.

\section{Teknik dan Alat Pengumpul Data}

Teknik pengumpul data dalam penelitian ini dilakukan tes kesegaran jasmani Indonesia (TKJI) untuk usia remaja umur 13 - 16 tahun pusat Pengembangan Kualitas Jasmani Kementerian Pendidikan Nasional yang terdiri dari

1. Lari cepat 60 meter

2. Angkat tubuh selama 60 detik (pull up) untuk putra dan gantung siku tekuk untuk putri

3. Baring duduk selama 60 detik (sit up)

4. Lari 1200 meter putra,

Sebelum melaksanakan tes sampel terlebih dahulu dikumpulkan dan diberikan penjelasan, untuk pelaksanaan dari masingmasing tes dapat diuraikan sebagai berikut:

1. Tes lari cepat 60 meter

Lari cepat mempunyai unsur kecepatan (speed) daya kejut (explosive power) dan koordinasi gerak. Tes dilakukan pada lintasan yang lurus, datar dan tidak licin berjarak 60 meter dengan pelaksanaan sebagai berikut : 
a. Pelaksanaan

1. Sikap permulaan

Peserta berdiri dibelakang garis start

2. Gerakan

a.Pada aba-aba "SIAP" peserta mengambil sikap start berdiri, siap untuk lari.

b. Pada aba-aba "YA" peserta lari secepat mungkin menuju garis finish menempuh jarak 60 meter.

3. Lari masih bisa diulang apabila a.Pelari mencuri start;

b. Pelari tidak melewati garis finish

c.Pelari terganggu dengan pelari yang lain

4. Pengukuran Waktu

Pengukuran waktu dilakukan dari saat bendera diangkat sampai pelari tepat melintasi garis finish

b. Hasil yang dicatat

1) Hasil yang di catat adalah waktu yang dicapai oleh pelari untuk menempuh jarak 60 meter, dalam satuan detik waktu.

2) Waktu dicatat satu angka dibelakang koma.

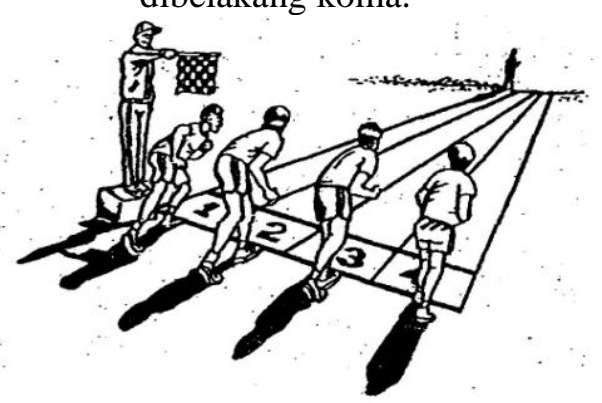

Gambar 2

Sikap start berdiri tes lari cepat 60 meter

(Kesegaran Jasmani Indonesia 2013)

2. Tes angkat tubuh untuk putra (60 detik)

Komponen kesegaran Jasmani yang mempunyai unsur kekuatan otot lengan dan peiut., Caranya sebagai berikut

a.Sikap permulaan

- Berdiri tegak, kedua tangan ke atas dan berpegangan tangan pada palang tunggal dengan kedua tangan di buka selebar bahu

- Telapak tangan menghadap ke kepala dengan ibu jari di antara palang dan kepala

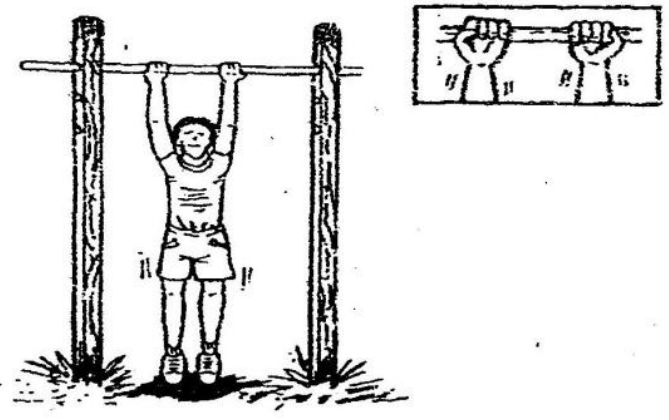

Gambar 3

Sikap Badan yang benar pada tes angkat tubuh putra

(Kesegaran Jasmani Indonesia 2013)

b. Gerakan

- Mengangkat tubuh dengan membengkokkan kedua lengan sehingga dagu menyentu atau berada diatas palang tunggal, kemudian kembali kesikap permulaan. Gerakan ini dihitung satu kali.

- Selama melakukan gerakan mulai dari kepala sampai ujung kaki tetap merupakan garis lurus.

- Gerakan ini dilakukan berulangulang, tanpa istirahat, sebanyak mungkin selama 60 detik.

c.Angkatan dianggap gagal dan tidak dapat dihitung apabila

- Pada Waktu mengangkat badan, peserta melakukan gerakan mengayun.

- Pada waktu mengangkat badan, dagu tidak menyentuh palang tunggal.

- Pada waktu kembali ke sikap permulaan kedua lengan tidak lurus.

d. Pencatat Hasil

- Yang dihitung adalah angkatan yang dilakukan dengan sempurna

- Yang dicatat adalah angkatan yang dilakukan dengan sikap sempurna tanpa istirahat selama 60 detik. 


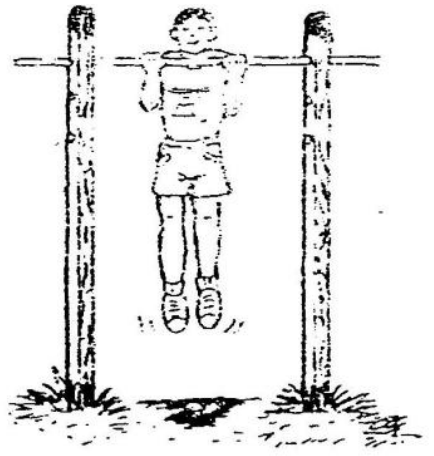

Gambar 4

Sikap dagu menyentuh/melewati palang tunggal

3. Baring duduk 60 detek (sit up)

Komponen kesegaran jasmani mempunyai unsur, kekuatan otot, perut, daya tahan otot perut, dan kelenturaan caranya sebagai berikut

a.Sikap permulaan

- Berbaring telentang di lantai, kedua lutut ditekuk dengan sudut $90^{\circ}$ dengan kedua jari-jarinya diletakkan dibelakang kepala.

- Peserta lain menekan/memegang kedua pegelangan kaki agar kaki tidak terangkat.

b. Gerakan

Mengangkat togok sampai kedua siku menyentuh paha, kemudian ke sikap pemula, gerakan ini dilakukan berulang kali tanpa istirahat sebanyak mungkin selam 60 detik.

c.Catatan

Gerakan dianggap gagal. apabila :

- Ketika mengangkat togok, siku meyentuh paha

- Tangan terlepas ketika, kembali ke sikap semula, tangan tidak menyentuh lantai
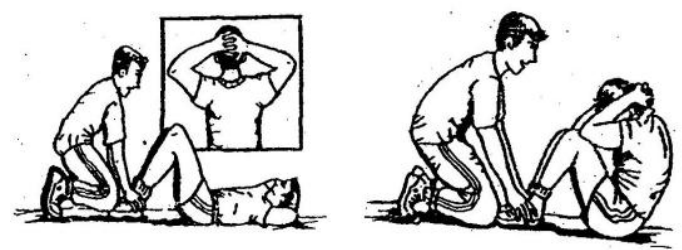

Gambar 5

Peserta bergerak mengambil sikap duduk sehingga kedua siku menyentuh paha

(Kesegaran Jasmani Indonesia 2013)
Komponen kesegaran jasmani yang mempunyai unsur, daya tahan kejut (explosive power)

a.Pelaksanaan

1) Sikap permulaan

a) Terlebih dahulu ujung jari tangan peserta dioles dengan serbuk kapur atau magnesium karbonat

b) Peserta berdiri tegak dekat dinding, kaki rapat, papan Skala berada disamping kiri atau kanannya. Kemudian tangan yang dekat dinding diangkat lurus ke atas telapak tangan ditempelkan pada papan berskala, sehingga meninggalkan berkas raihan jarinya.

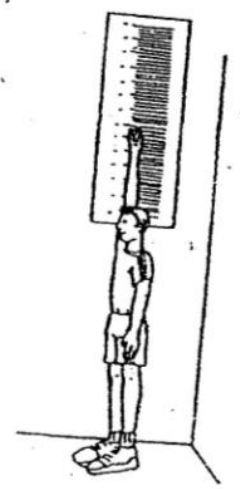

Gambar, 6

Sikap mementukan raihan tegak

(Kesegaran Jasmani Indonesia 2013)

2) Gerakan

a) Peserta mengambil awalan dengan sikap menekukkan lutut dan kedua lengan diayun kebelakang kemudian peserta meloncat setinggi mungkin sambil menepuk papan dengan tangan yang terdekat sehingga menimbulkan berkas.

4. Tes loncat tegak 


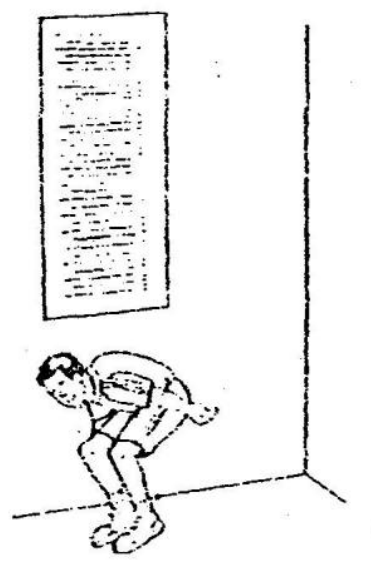

Gambar 7

Sikap awalan loncat tegak

(Kesegaran Jasmani Indonesia 2013)

b) Ulangi loncatan ini sampai 3 kali berturut-turut

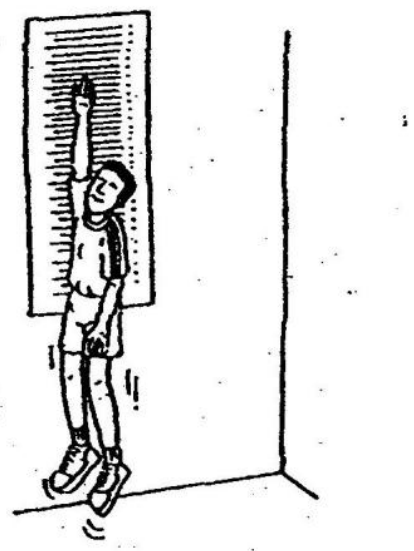

Gambar 8

Gerakan meloncat tegak

(Kesegaran Jasmani Indonesia 2013)

b. Pencatat Hasil

1) Selisih raihan loncatan dikurangi raihan tegak

2) Ketiga selisih raihan dicatat

5. Tes lari/jalan jarak 1000 meter

Komponen kesegaran jasmani ini mempunyai unsur, daya tahan paru- paru dan kardiovaskuler berserta otot tungkai. Pelaksanaannya sebagai berikut :

a.Pelaksanaan

1) Sikap permulaan

- Peserta berdiri dibelakang garis start

2) Gerakan

a) Pada. aba-aba "SIAP" peserta mengambil sikap start berdiri, siap untuk lari.

b) Pada. aba-aba "YA" peserta berlari, menempuh jarak 1000 meter.

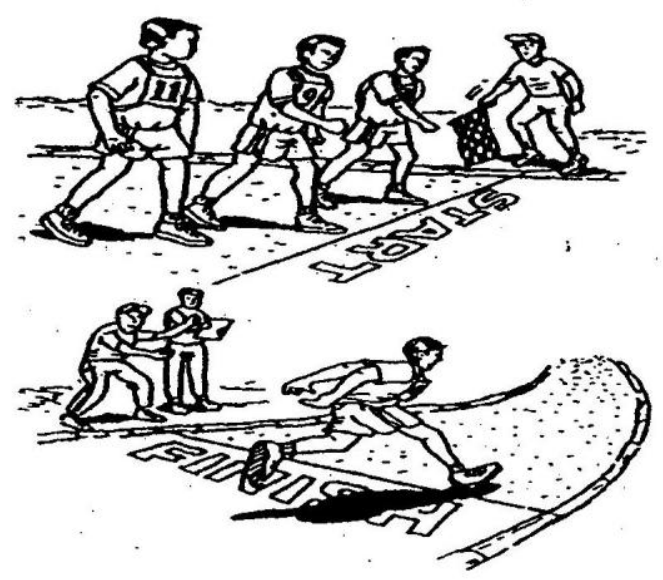

Gambar 9

Test lari 1200 meter

(Kesegaran Jasmani Indonesia 2013)

3) Pencatat hasil

a) Pengambilan waktu dilakukan mulai saat bendera start diangkat sampai peserta tepat melintasi garis finish.

b) Hasil yang dicatat adalah waktu yang dicapai oleh pelari untuk menempuh jarak 1000 meter. Waktu yang dicatat dalam satuan menit dan detik.

Contoh penulisan

Seorang pelari dengan adil waktu 3 menit 12 detik 3'12'

\section{A. Instrumen/ Alat Pengumpul Data}

\section{Penelitian}

Melalui penukuran yang telah dilakukan setiap sampel dipilih degunakan alat-alat pengumpulan data primer terhadap kesegaran jasmani yang terdiri dari:

a. Lintasan lari/lapangan yang datar dan tidak licin

b. Stopwatch

c. Bendera Start

d. Tiang Pancang

e. Nomor Dada

f. Palang tunggal untuk gantung siku

g. Papan berskala untuk papan loncat

h. Serbuk kapur

i. Penghapus

j. Formulir tes

k. Peluit dan alat tulis

Penilaian kesegaran jasmani Indonesia untuk anak umur $10-12$ tahun 
yang dikemukakan Pusat Kesegaran Jasmani dan Rekreasi (1999:24) adalah sebagai berikut:

\section{B. Teknik Analisa Data}

Seperti yang dikemukakan sebelumnya bahwa bentuk penelitian adalah deskriptif dengan tujuan untuk melihat tingkat kesegaran jasmani sisawa putra yang mengikuti ekstrakurikuler gulat di SPM Negeri 30 Padang, maka teknis analisis data yang dipakai adalah teknik persentase yaitu apabila suatu penelitian bertujuan untuk mendapatkan gambaran atau menemukan sesuatu sebagaimana adanya tentang suatu objek yang diteliti. Maka teknik analisis datanya yang diperlukan cukup dengan perhitungan persentase, (\%). Data yang diperoleh dalam penelitian ini akan di olah sesuai dengan tujuan dari penelitian dengan melihat hasil data tingkat kesegaran jasmani dari masing-masing siswa dengan rumus persentase Sudijono (1991:40) berikut:

$$
\mathrm{P}=\frac{\mathrm{F}}{\mathrm{N}} \times 100 \%
$$

Keterangan :

$\mathrm{P}=$ Persentase

$\mathrm{F}=$ Frekwensi

$\mathrm{N}$ = Jumlah Sampel

Untuk menentukan tingkat acuan klasifikasi tingkat pencapaian sampel digunakan klasifikasi menurut Sudjana (1989 :55) sebagai berikut :

$$
\begin{array}{ll}
90-100 \% & =\text { Sangat Baik } \\
80-89 \% & =\text { Baik } \\
65-79 \% & =\text { Cukup } \\
55-64 \% & =\text { Kurang } \\
0-54 \% & =\text { Kurang Sekali }
\end{array}
$$

Tabel 3

\section{Kriteria Nilai TKJI}

(Untuk Putra Usia 16 - 19 Tahun)

\begin{tabular}{|c|c|c|c|c|c|c|}
\hline $\begin{array}{c}\text { Nil } \\
\text { ai }\end{array}$ & $\begin{array}{c}\text { Lari 60 } \\
\text { Cepat }\end{array}$ & $\begin{array}{c}\text { Gantung } \\
\text { Angkat } \\
\text { Tubuh }\end{array}$ & $\begin{array}{c}\text { Baring } \\
\text { Duduk }\end{array}$ & $\begin{array}{c}\text { Loncat } \\
\text { Tegak }\end{array}$ & $\begin{array}{c}\text { Lari 1200 } \\
\text { Meter }\end{array}$ & Nilai \\
\hline 5 & s.d -7,2" & 19 keatas 41 keatas & 73 keatas & s.d - 3'14" & 5 \\
\hline 4 & $\begin{array}{l}7,3^{\prime \prime} \\
8,3^{\prime \prime}\end{array}$ & $14-8$ & $30-40$ & $60-72$ & $3^{\prime} 15^{\prime \prime}-4 ' 25 "$ & 4 \\
\hline 3 & $8,4-9,6^{\prime \prime}$ & $9-13$ & $21-29$ & $50-59$ & $\begin{array}{c}4^{\prime} 26^{\prime \prime}- \\
5^{\prime} 12^{\prime \prime}\end{array}$ & 3 \\
\hline 2 & $9,7-11,0^{\prime \prime}$ & $5-8$ & $10-20$ & $39-49$ & $5^{\prime} 13^{\prime \prime}-6 ' 33 "$ & 2 \\
\hline 1 & $\begin{array}{l}11,1^{\prime \prime} \\
\text { dst }\end{array}$ & $0-4$ & $0-9$ & $38-$ dst & $6^{\prime} 34 "-$ dst & 1 \\
\hline
\end{tabular}

Tabel 4

Norma Tes Kesegaran Jasmani Indonesia (Untuk Putera dan Putri)

\begin{tabular}{|c|c|ll|}
\hline No & Jumlah Nilai & \multicolumn{2}{|c|}{ Klasifikasi Kesegaran Jasmani } \\
\hline 1 & $22-25$ & \multicolumn{3}{|l|}{ Baik Sekali } & (BS) \\
\hline 2 & $18-21$ & Baik & (B) \\
\hline 3 & $14-17$ & Sedang $\quad$ (S) \\
\hline 4 & $10-13$ & Kurang (K) \\
\hline 5 & $5-9$ & \multicolumn{2}{|c|}{ Kurang Sekali (KS) } \\
\hline
\end{tabular}

\section{HASIL DAN PEMBAHASAN}

Pada bab ini akan diuraikan deskripsi data dan pembahasan tentang tingkat kesegaran jasmani siswa Putera yang mengikuti ekstrakurikuler gulat di SMP Negeri 30 Padang. Deskripsi data pada penelitian ini dapat dilihat pada bagian berikut, dan dilanjutkan dengan pembahasan.

Sesuai dengap jenis data yang diperlukan, maka deskripsi data dilakukan dengan bentuk tes. Hal ini bertujuan untuk melihat tingkat kesegaran jasmani siswa Putera yang mengikuti ekstrakurikuler gulat di SMP Negeri 30 Padang.

Berdasarkan uraian terdahulu, maka seterusnya dilakukan analisa data dan pembahasan mengenai hasil penelitian dengan menggunakan metode deskriptif, data yang telah diolah kemudian ditafsirkan sehingga mampu mengungkapkan sebagaimana adanya tentang tingkat kesegaran jasmani tersebut. Di bawah ini merupakan distribusi frekuensi dari variabel yang telah diteliti:

1. Tinjauan Tingkat Kesegaran Jasmani pada Siswa Putera Yang Mengikuti Ekstrakurikuler Gulat di SMP Negeri 30 Padang.

a. Tingkat Kesegaran Jasmani Siswa Putera Yang Mengikuti Ekstrakurikuler Gulat di SMP Negeri 30 Padang.

Berdasarkan tes yang dilakukan pada siswa Putera yang mengikuti ekstrakurikuler gulat di SMP Negeri 30 Padang, maka dapat dilihat pada tabel distribusi frekuensi di bawah ini:

\section{Tabel 5}

Distribusi Frekuensi Tingkat Kesegaran Jasmani Siswa Putera yang mengikuti ekstrakurikuler gulat di SMP Negeri 30 Padang

\begin{tabular}{|c|c|c|c|c|}
\hline No & $\begin{array}{c}\text { Kelas } \\
\text { Interval }\end{array}$ & Kategori & $\begin{array}{c}\text { Frekuensi } \\
\text { Absolut }\end{array}$ & $\begin{array}{c}\text { Frekuensi } \\
\text { Relatif }\end{array}$ \\
\hline 1 & $22-25$ & Baik Sekali & 5 & $12.5 \%$ \\
\hline 2 & $18-21$ & Baik & 28 & $70 \%$ \\
\hline 3 & $14-17$ & Sedang & 7 & $17.5 \%$ \\
\hline 4 & $10-13$ & Kurang & 0 & 0 \\
\hline 5 & $5-9$ & Kurang Sekali & 0 & 0 \\
\hline
\end{tabular}

Berdasarkan distribusi frekuensi di atas 
maka dapat dilihat bahwa tidak ada siswa yang memiliki tingkat kesegaran jasmani pada kategori baik sekali, 5 orang $(12.5 \%)$ siswa mempunyai tingkat kesegaran jasmani pada kategori baik, 28 orang (70\%) siswa mempunyai tingkat kesegaran jasmani pada kategori sedang, 7 orang (17.5\%) dan tidak ada siswa yang memiliki tingkat kesegaran jasmani pada kategori kurang dan kurang sekali. Berdasarkan hasil penelitian mengenai tingkat kesegaran jasmani, dapat diketahui bahwa $70 \%$ siswa Putera yang mengikuti ekstrakurikuler gulat di SMP Negeri 30 Padang baik. Untuk lebih jelasnya dapat dilihat pada grafik berikut:

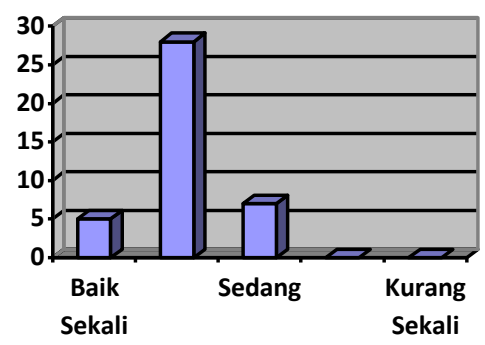

\section{Grafik 1 \\ Grafik Freknensi Tingkat Kesegaran Jasmani Siswa Putera yang mengikuti ekstrakurikuler gulat di SMP Negeri 30 Padang}

\section{Pembahasan}

1. Tingkat Kesegaran Jasmani Siswa Putera Yang Mengikuti Ekstrakurikuler Gulat di SMP Negeri 30 Padang

Berdasarkan hasil distribusi frekuensi data yang telah diuraikan di atas maka diperoleh kesimpulan mengenai tingkat kesegaran jasmani pada Putera yang mengikuti ekstrakurikuler gulat di SMP Negeri 30 Padang yang menjadi objek penelitian. Dari hasil pengolahan data diperoleh data tingkat kesegaran jasmani pada siswa Putera yang mengikuti ekstrakurikuter gulat di SMP Negeri 30 Padang sebesar 70\% dalam kategori baik, dari hasil tersebut dapat dilihat tingkat kesegaran jasmani rats-rata siswa yang mengikuti ekstrakurikuler gulat di SMP Negeri 30 Padang baik.

Kesegaran jasmani adalah salah satu faktor yang menentukan dalam kehidupan sehari-hari. Begitu juga bagi siswa yang belajar pendidikan jasmani olahraga kesehatan sangat memerlukan sekali ketekunan serta daya tahan tubuh yang lebih tinggi dalam mengikuti materimateri pelajaran pendidikan jasmani dan olahraga.
Kesegaran jasmani merupakan kemampuan tubuh seseorang untuk melakukan pekerjaan sehari-hari tanpa menimbulkan kelelahan yang berarti. Kesegaran jasmani merupakan salah satu hal yang penting bagi tercapainya tujuan proses belajar mengajar di sekolah. Seseorang tidak akan mendapatkan hasil belajar yang baik (optimal) tanpa disertai dengan kesegaran jasmani yang baik. Dengan demikian kesegaran jasmani merupakan faktor yang sangat penting dalam kaitannya dengan kemampuan dan keberhasilan belajar seseorang.

Masih kurangnya tingkat kesegaran jasmani pada siswa Putera yang mengikuti ekstrakurikuler gulat di SMP Negeri 30 Padang ini juga dipengaruhi oleh faktor kurangnya aktifitas fisik yang teratur ditakukan oleh siswa Putera yang mengikuti ekstrakurikuler gulat di SMP Negeri 30 Padang. Salah satu faktornya adalah kegiatan ekstrakurikuler diluar Jam sekolah kurang diminati oleh siswa. Selain itu juga dipengaruhi oleh perkembangan teknologi yang meningkat pesat. Selain itu untuk meningkatkan kesegaran jasmani anak, tentu orang tua harus menyeleksi bentuk-bentuk permainan yang dilakukan dan dapat merangsang komponen - komponen kesegaran jasmani seperti: ketahanan jantung paru, kekuatan otot, ketahanan otot, komposisi tubuh dan fleksibilitas. Dapat dicontohkan bila anakanak lebih banyak melakukan kegiatan permainan pasif, maka orang tua berusaha mendorong untuk melakukan bentuk permainan aktif

Bagi guru Penjas Orkes, merupakan tanggung jawabnya karena tujuan penjas adalah untuk meningkatkan kesegaran jasmani siswanya. Bila siswanya mempunyai kesegaran jasmani rendah berarti pembelajaran yang diberikan tidak dapat mencapai sasaran. Untuk itu guru perlu kembali mengevaluasi program pembelajaran yang telah disusunnya,

\section{KESIMPULAN}

Berdasarkan hasil penelitian yang telah diuraikan pada bab terdahulu mengenai tingkat kesegaran jasmani pada siswa Putera yang mengikuti ekstrakurikuler gulat di SMP Negeri 30 Padang, maka dapat diambil kesimpulan sebagai berikut: Tingkat kesegaran jasmani dari 40 siswa Putera yang mengikuti ekstrakurikuler gulat di SMP Negeri 30 Padang dapat dilihat 5 orang $(12,5 \%)$ baik sekali, 28 orang (760/o),baik, 7 orang $(17,5 \%)$ sedang, dan tidak ada siswa yang masih berada pada kategori 
kurang dan kurang sekali.

\section{DAFTAR PUSTAKA}

Ardle, Mc., Katch, WD, F.I., Klatch, 1981, Exercise Physiology. Energy, Nutrition an Human Performance, Philadelpia : Lea Febiger,

Arikunto, 1996. Prosedur Penelitian. Jakarta : Rineka Cipta

Arikunto. 1998.Prosedur penelitian suatu pendekatan praktek.Jakarta : Rineka Cipta

Arikunto,2002, manajemen penelitian, jakarta : Reneka Cipta

Arsil,2008,pembinaan kondisi fisik, padang : Dip.Universitas Negeri Padang

Astrand, P.O. Rodhahl, K 1986, Textbooks of Work Physiology 3rd ed, New York:Mc Graw-Hill Company,

Brooks, G.A., Fahley, T.D. 1984 Excercise Physiology ; Human Bioenergetics and its Application, New York : 1st John, Wilwy and Son Inc.

Dangsina Moeloek, 1984, Dasar Fisiologi Kesegaran Jasmani dan Latihan, Jakarta: Universitas Indonesia.

Fox, E.L. Mathew, DK, 1981, The Physiology Basis of Education and Athletics, Philadelphia : Saunders College Publishing

Fox, E.L. 1984, Sport Physiologi, 2nd Tokyo : WB Saunders Book Co.

Fox, EL, Bower. R.W. Foss. M.L., 1988, The Physiologi Basis odf Physical Education anf Athletics, Fourth Editions Saunders College Publisher.

Gabbard, C, Le Blanc E. Lowy, S. 1987, Physical Education for Children Building The Foundation, New Jersey : Prentice Hall Inc Englewood Cliffs

Garis-garis Besar Haluan Negara, TAP MPR No. II/MPR/1993, Jakata : Pidato
Pertanggungjawaban Presiders RI

Golding Lawrence,A. Bos. Roland R, 1970, Scientific Foundations of Physical Education Program, Mineapolis : Burger Publishing Company.

Gusril,2004, perkembangan motorik paas masa anak-anak. Jakarta :Dirjen Olahraga Departemen Pendidikan Nasional

Hellenbrant, E., Hontz.S. 1973, Mechanisms of Muscle Training and Man, Jurnal Applic Physiol

Karpovic Peter, V, 1963, Physiology of Muscular Activity, Fifth Edition, Philadelpia WB Saunders Company.

1988. Peningkatan dan Pembinaan Kekuatan Kondis Fisik Dalam Olahraga, Semarang : Dahara Prize.

Sadoso Sumosardjono, 1984. Latihan Olahraga Bagi Orang Dewasa. Jakarta: Pusat Ilmu Olahraga — KONI PUSAT

1988 Metodologi Research I, II dan $I V$, Yogyakarta : Andi Offset

1990 Metodologi Research I, II dan IV, Yogyakarta: Andi Offset

Suharsimi Arikunto, 2000.Prosedur Penefitian Suatu Pendekatan Praktek Jakarta. PT. Rineka Cipta.

Strauss, R.H, 1988. Sport Medicine, Philadelphia : WB Saunders Company.

Syafruddin,1996, pengantar ilmu melatih. Padang : FPOK IKIP Padang

UNP.2010, buku panduan penulisan tugas akhir skripsi universitas negeri padang. Padang :UNP

UU RI No.3, 2005, Sistem keolahragaan Nasional. Jakarta: Menegpora Vancic, Mark, 1979. Lari 1200 Meter 